University of Nebraska - Lincoln

DigitalCommons@University of Nebraska - Lincoln

Biological Systems Engineering: Papers and

Publications

Biological Systems Engineering

$9-1981$

\title{
Vegetative Filter Treatment of Livestock Feedlot Runoff
}

\author{
Elbert C. Dickey \\ University of Nebraska at Lincoln, edickey1@unl.edu \\ D. H. Vanderholm \\ University of Illinois
}

Follow this and additional works at: https://digitalcommons.unl.edu/biosysengfacpub

Part of the Biological Engineering Commons

Dickey, Elbert C. and Vanderholm, D. H., "Vegetative Filter Treatment of Livestock Feedlot Runoff" (1981). Biological Systems Engineering: Papers and Publications. 290.

https://digitalcommons.unl.edu/biosysengfacpub/290

This Article is brought to you for free and open access by the Biological Systems Engineering at DigitalCommons@University of Nebraska - Lincoln. It has been accepted for inclusion in Biological Systems Engineering: Papers and Publications by an authorized administrator of DigitalCommons@University of Nebraska Lincoln. 


\title{
Vegetative Filter Treatment of Livestock Feedlot Runoff ${ }^{1}$
}

\author{
ELBERT C. DICKEY AND DALE H. VANDERHOLM ${ }^{2}$
}

\begin{abstract}
Four vegetative filters were installed on feedlots in central and northern Illinois. Two configurations were used: channelized flow and overland flow. After settling for partial solids removal, runoff was applied directly to the filters and allowed to flow from the inlet to the outlet section. Results from measurement analyses and sampling of influent, effluent, and surface flow at intermediate points were reported.

Most runoff events were infiltrated completely, resulting in no filter discharge. Runoff from larger events was partially discharged. Filters removed as much as $95 \%$ of nutrients and oxygen-demanding materials from the applied runoff on a weight basis, and $80 \%$ on a concentration basis. Removal was directly related to flow distance or contact time with the filter. Channelized flow with greater flow depths required greater contact time or flow distance than shallow overland flow to achieve the same level of treatment.
\end{abstract}

Additional Index Words: nutrients, water quality, land application, pollution.

Dickev. E. C., and D. H. Vanderholm. 1981. Vegetative filter treatment of livestock feedlot runoff. J. Environ. Qual. 10:279-284.

Many livestock feedlots are not subject to the National Pollutant Discharge Elimination System (NPDES) permit program. While most are small feedlots, some have a potential water pollution problem because of uncontrolled runoff from open lot areas. Installation of a zero-discharge runoff-control system is one method of solving this pollution threat. But this approach is economically prohibitive for many small operations, ${ }^{3}$ even though the zero-discharge system is required in several states. An alternative is a vegetative filter system which adequately controls runoff so that violations of water

\footnotetext{
' Contribution of the U.S. Environmental Protection Agency, Illinois Inst. for Environ. Qual., The Ill. Agric. Exp. Sta. and the Illinois Beef Industry Coun. Received 13 Jan. 1981

${ }^{2}$ Assistant Professor, Dep. of Agric. Eng., Univ. of Nebraska, Lincoln; and Associate Professor, Dep. of Agric., Univ. of Illinois, Urbana, respectively.

${ }^{3} D$. Lybecker. 1977. Comparative surface runoff control system investment and operating costs for six Illinois demonstration-research sites. Paper presented at Southern Illinois Univ. Liquid Livestock Waste Disposal Field Day, Dep. of Agric. Ind. Southern Illinois Univ., Carbondale.
}

quality standards will not occur during storm runoff. This alternative has the advantage of controlling runoff at lower cost than conventional zero-discharge systems, and requires less management.

Vegetative filters are systems in which a vegetative area such as pasture, grassed waterway, or even cropland is used for treating feedlot runoff by settling, filtration, dilution, absorption of pollutants, and infiltration. Mather (1969) reported removal of biochemical oxygen demand (BOD) from cannery wastes of $94-99 \%$ during overland flow in a disposal area, although Bendixen et al. (1969) reported only $66 \%$ BOD removal. Nitrogen removals of $61-94 \%$ and phosphorus removals of $39-81 \%$ were also reported in these two studies.

McCaskey et al. (1971) found a renovating effect for livestock waste water traveling over a grassed surface in a thin layer, but did not determine the effect on a quantitative basis. Edwards et al. (1971) measured significant reductions in the nutrient content of feedlot runoff after the runoff traversed a grassed waterway. Reduction was attributed to deposition of solids in the waterway and to dilution of feedlot runoff by surface water from nearby cropland. Kramer et al. (1974) indicated that possibly spray-runoff was satisfactory for removal of BOD and total suspended solids from beef feedlot runoff, but that nutrient levels could still be too high for discharge to be practical.

Sievers et al. (1975) used a grassed waterway filter to treat anaerobic swine lagoon effluent. Willich and Boda (1976) also treated swine lagoon effluent with sloping grass strips. Open feedlot runoff-treatment systems have been reported by Sutton et al. (1976) and Swanson et al. (1975). Most early systems were designed on the premise that all or most of the feedlot runoff from storms would infiltrate into the soil, with the uninfiltrated runoff being adequately treated so that it could enter surface watercourses. However, no uniform design criteria has been developed, and variable performance has made environmental authorities hesitant to give blanket approval to this concept.

A study was begun in 1975 to further evaluate vegetative filter systems. The study was conducted year-round for over 2 years. Its objective was to determine whether or not vegetative filters are feasible alternatives for management of feedlot runoff. 


\section{MATERIALS AND METHODS}

Channelized flow and overland flow systems were studied. Channelized flow systems have various configurations such as a graded terrace channel or grassed waterway, and are systems in which flow is concentrated in a relatively narrow channel. One channelized flow system was a graded terrace that traversed a hillside several times in a serpentine fashion. The other channelized flow system had one section of graded terrace channel followed by a section of grassed waterway. In overland systems, flow occurs as sheet flow generally $<30 \mathrm{~mm}$ deep, with widths ranging from 5 to $30 \mathrm{~m}$.

Four feedlots were selected in which vegetative filters were welladapted to the physical situation and appeared to have a reasonable chance for managing feedlot runoff. At all locations, the basic system consisted of a settling facility, a distribution component, and one of the two types of vegetative filter illustrated in Fig. 1. No storage unit for runoff was involved. Runoff from storms went directly to the filter area. Similar concrete settling basins were used at each location, but each vegetative filter was quite different. One system was installed on the University of Illinois dairy farm, and the other three systems were at commercial livestock production facilities.

At the University of Illinois dairy facility (System 1), effluent from the settling basin was pumped by an automatic pump (controlled by the water level) through a gated irrigation-pipe distribution system, spreading the effluent on three field plots, each 12 by $91 \mathrm{~m}$ and with a slope of about $0.5 \%$. One grass species was seeded on each plot. Species used were reed canarygrass (Phalaris arundinacea L.) smooth bromegrass (Bromus inermis Leyss.), and orchardgrass (Dactylis glomerta L.). Each plot was surrounded by a berm to prevent any outside drainage water from entering and any applied effluent and rainfall from discharging, except at the controlled plot outlet. A control plot, planted to smooth bromegrass, received no effluent applications. The flow over the plots was intended to approximate sheet or overland flow. The ratio between the vegetative filter area and feedlot area was about $1: 1$.

System 2 was also an overland flow type and was installed to control the runoff from a beef feedlot holding about $\mathbf{4 5 0}$ cattle. The facility obtained an NPDES permit, which allowed use of the vegetative filter area. This was a gravity-flow system, with runoff distributed across the upper end of a sloping vegetated area. Initially, runoff was distributed through a perforated plastic pipe $15.2 \mathrm{~cm}$ in diameter. Later, a rigid plastic pipe was split to form a weir. The vegetative filter area was seeded to a fescue (Festuca arundinacea Schreb.) and alfalfa (Medicago sativa $\mathrm{L}$.) mixture. Since the soil was sandy, a filter area to lot area ratio of $0.7: 1$ was used. The constructed filter, 27 by $61 \mathrm{~m}$, had a slope of about $2 \%$.

System 3 was on a beef feedlot holding 500 cattle. Runoff was directed to a channelized flow vegetative filter (graded terrace) patterned after the serpentine waterway system studied by Swanson et al. (1975). The terrace channel was about $564 \mathrm{~m}$ long and had a parabolic

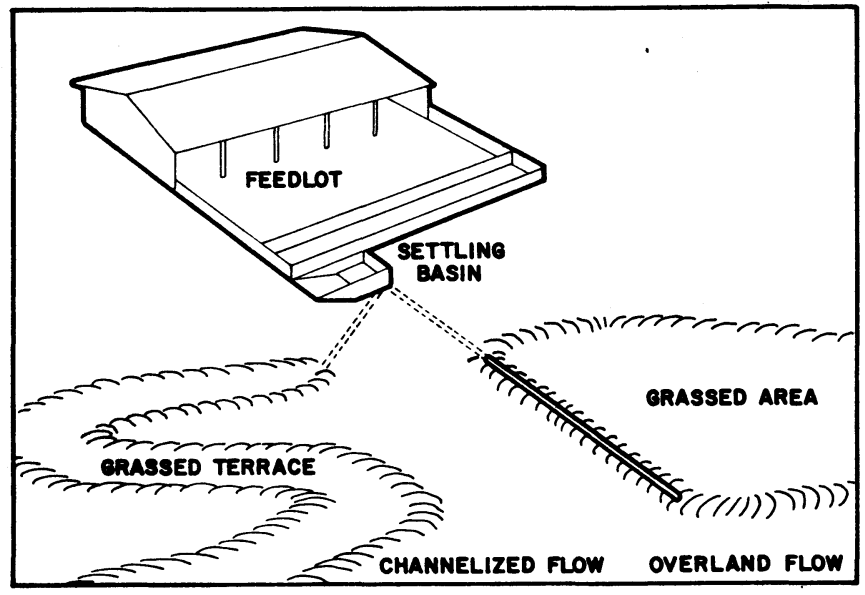

Fig. 1-Alternative configurations for vegetative filters used as a treatment for feedlot runoff. cross-section with a top width of $8.5 \mathrm{~m}$ and a depth of $0.9 \mathrm{~m}$. The channel slope was $0.25 \%$.

System 4 was on an uncovered swine-finishing facility holding $\mathbf{4 8 0}$ animals. Runoff entered a vegetated terrace channel seeded with garrison creeping foxtail (Alopecurus arundinaceus Poir). Runoff traversed $152 \mathrm{~m}$ of terrace channel and $457 \mathrm{~m}$ of grassed waterway before reaching a defined watercourse. The terrace channel slope was $0.25 \%$ and the waterway was $2 \%$.

\section{Experimental Procedures}

A recording rain gauge was used to collect rainfall data at each site. For System 1, the quantity of runoff applied to plots was calculated from records of elapsed pumping time and pump calibration curves. Applied runoff in System 3 was measured with an $\mathrm{H}$-type flume and a water-stage recorder at the channel inlet. Applied runoff quantities were estimated for Systems 2 and 4 by using rainfall data and previously developed rainfall-runoff relationships for feedlots in Illinois (Dickey and Vanderholm, 1977).

Each site was equipped with automatic samplers capable of taking 24 discrete 550-ml samples. In addition, three composite type automatic samplers were used at System 1. At each automatic sampler location H-type flumes with stage recorders were used to measure the flow rate. Samplers and flumes were located at each filter outlet and also at intermediate points on System 3. All samplers were flow-activated, and usually set to take a 500-ml sample at 45 -min intervals. Automatic samples were augmented by grab sampling along the flow length. Grab samples of runoff entering the filters were taken periodically. At System 3, the sampler location during 1976 was $305 \mathrm{~m}$ downslope from the settling basin discharge. In 1977, two samplers were positioned at 229 and $381 \mathrm{~m}$ from the basin discharge until midsummer, after which the sampler at $229 \mathrm{~m}$ was moved to $533 \mathrm{~m}$.

Samples were analyzed for ammonia and Kjeldahl-N according to Bremner and Keeny (1965), and solids, conductivity, chloride chemical oxygen demand (COD), BOD, and total $\mathrm{P}$ and $\mathrm{K}$, according to Methods for Chemical Analysis of Water and Waste (USEPA, 1974). Filter influent and effluent samples from System 1 were analyzed for fecal coliform and fecal streptococcus according to Standard Methods (APHA, 1975).

\section{RESULTS AND DISCUSSION}

Average concentrations in the filter effluent at System 1 represented a reduction of about $80 \%$ from concentrations in the settling-basin effluent (Table 1). Both COD and BOD levels were reduced to $85 \%$ of those in the basin effluent. The filter discharge had an average BOD concentration of $165 \mathrm{mg} /$ liter, but only a limited number of BOD measurements were obtained. However, filter effluent volume for the sampling period was considerably less than basin effluent volume because infiltration occurred in the filter area. The filter effluent volume was $413 \mathrm{~m}^{3}$ while the filter area received 2,453 $\mathrm{m}^{3}$ of feedlot runoff. On a weight basis, an average of

Table 1-Constituent concentrations and constituent retention on a weight basis for vegetative filter System I.

\begin{tabular}{|c|c|c|c|c|}
\hline Constituent & $\begin{array}{c}\text { Settling } \\
\text { basin } \\
\text { effluent }\end{array}$ & $\begin{array}{l}\text { Vegetative } \\
\text { filter } \\
\text { effluent } \dagger\end{array}$ & $\begin{array}{l}\text { Concen- } \\
\text { tration } \\
\text { reduction }\end{array}$ & $\begin{array}{c}\text { Constituent } \\
\text { retention } \\
\text { (weight basis) }\end{array}$ \\
\hline & \multicolumn{2}{|c|}{- mg/liter -} & & $\%$ \\
\hline $\begin{array}{l}\mathrm{NH}_{3}-\mathrm{N} \\
\text { Total Kjeldahl-N } \\
\text { Total solids } \\
\text { COD } \\
\mathbf{P} \\
\text { K }\end{array}$ & $\begin{array}{c}134 \\
300 \\
3,700 \\
4,220 \\
64.1 \\
665\end{array}$ & $\begin{array}{c}18.5 \\
59.6 \\
996 \\
616 \\
14 \\
168\end{array}$ & \begin{tabular}{|l|l|}
86.2 & \\
80.1 & 73.1 \\
85.4 & 78.2 \\
74.7 & \\
\end{tabular} & $\begin{array}{l}\mathbf{9 7 . 7} \\
\mathbf{9 6 . 7} \\
\mathbf{9 5 . 5} \\
\mathbf{9 7 . 5} \\
\mathbf{9 6 . 3} \\
\mathbf{9 5 . 7}\end{array}$ \\
\hline Effluent volume & $2,453 \mathrm{~m}^{2}$ & $413 \mathrm{~m}^{3}$ & & 83.2 \\
\hline
\end{tabular}

† Average concentrations in samples taken at equal time intervals during discharge events. 


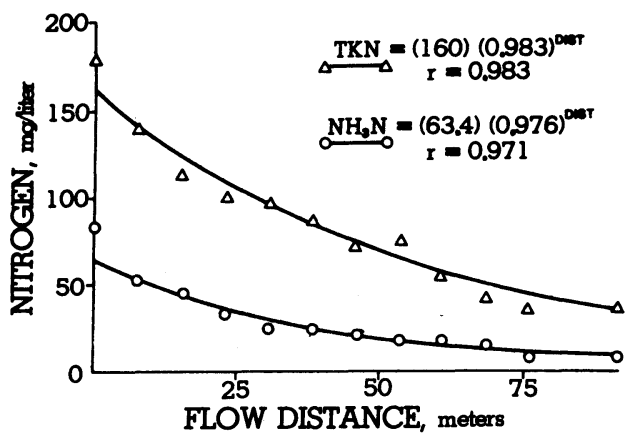

Fig. 2-Nitrogen concentration changes with overland flow (System 1).

about $96 \%$ of constituents applied were retained by the filter. Ammonia-N had the greatest reduction, showing a removal of $97.7 \%$; total solids had the least reduction, a removal of $95.5 \%$.

Samples from System 1 averaged $5.75 \times 10^{5}$ fecal coliforms $100 \mathrm{~m}^{-1}$ in discharge from the control plot that received no waste, $1.05 \times 10^{7} 100 \mathrm{ml}^{-1}$ in treated plot discharge, and $1.25 \times 10^{7} 100 \mathrm{ml}^{-1}$ in applied feedlot runoff. Fecal streptococcus averaged $1.8 \times 10^{3} 100$ $\mathrm{ml}^{-1}$ from the control plot, $1.1 \times 10^{\mathrm{s}} 100 \mathrm{ml}^{-1}$ in the treated-plot discharge, and $1.6 \times 10^{6} 100 \mathrm{ml}^{-1}$ in applied runoff. While some differences were indicated, the number of bacterial analyses was not large enough to analyze statistically. Bacteria levels were high in both the treatment and control plots, but the data were consistent with a previous study by Dornbush et al. (1974).

Figures 2 and 3 clearly show decreases in constituent concentrations as basin effluent traversed the vegetative filter at System 1. Data points on Fig. 2 and 3 are averages of grab samples obtained during seven different runoff events. The figures indicate that constituent concentrations approached background levels (and the stream standards) asymptotically as vegetative filter length increased, and that excessive flow lengths would be required to meet standards unless further dilution occurred.

While the filters were effective in removing pollutants, the effluent still had sufficiently high pollutant levels to cause a violation of stream water quality standards in some instances. Measured discharge rates from System 1 were low, averaging 1.70 liters $\mathrm{sec}^{-1}$, with a maximum observed discharge of 10.8 liters $\mathrm{sec}^{-1}$. This flow rate is quite small relative to many receiving stream flow rates during the storms.

Relatively high constituent concentrations were found in the filter effluent from System 2, as compared to System 1 (Table 2). System 1 was a dairy, cleaned daily

Table 2-Estimated pollutant removal in System 2 filter based on System 3 basin effluent concentrations.

\begin{tabular}{|c|c|c|c|}
\hline Constituent & $\begin{array}{l}\text { Settling basin } \\
\text { effluent }\end{array}$ & $\begin{array}{l}\text { Vegetative } \\
\text { filter effluent }\end{array}$ & $\begin{array}{c}\text { Constituent } \\
\text { reduction }\end{array}$ \\
\hline & \multicolumn{2}{|c|}{$\longrightarrow$ mg/liter $\longrightarrow$} & $\%$ \\
\hline $\begin{array}{l}\mathrm{NH}_{3}-\mathrm{N} \\
\text { Total Kjeldahl-N } \\
\text { Total solids } \\
\text { COD }\end{array}$ & $\begin{array}{r}608 \\
1,122 \\
12,777 \\
14,288\end{array}$ & $\begin{array}{r}173 \\
324 \\
4,710 \\
2,691\end{array}$ & $\begin{array}{l}71.5 \\
71.1 \\
63.1 \\
81.2\end{array}$ \\
\hline
\end{tabular}

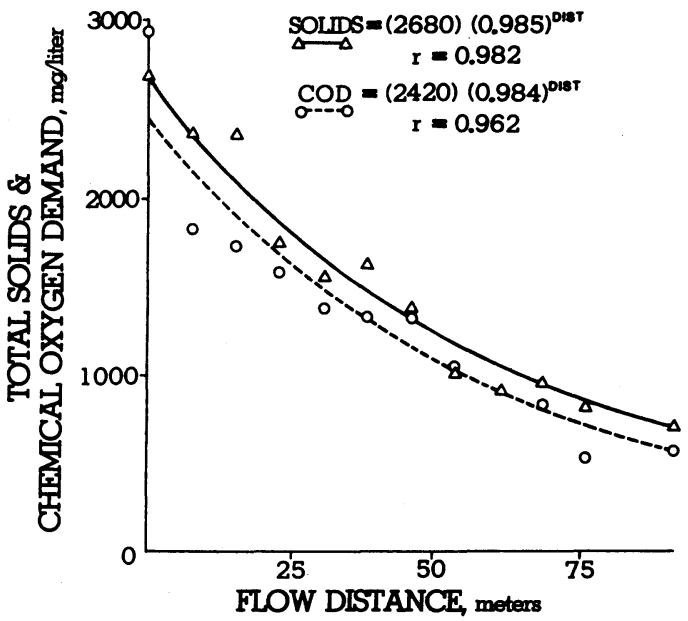

Fig. 3-COD and total solids concentration changes with overland flow (System 1).

when possible, but the beef feedlot in System 2 was only cleaned every 3 or 4 months. System 2 also had an animal density about 7 times that of System 1. Thus, there were much higher constituent concentrations in the feedlot runoff entering the settling basin at System 2 than in System 1. The settling basin at System 2 was cleaned infrequently, which meant a loss of settling capacity during many storms. These factors contributed to high concentrations of constituents in the settling basin effluent for System 2. As a result, the upper end of the vegetative filter at System 2 became a shallow but effective settling area, trapping large amounts of manure solids.

Representative samples of the settling basin effluent at System 2 were not obtained. Consequently the effluent from the settling basin at System 2, after traversing the first few meters of filter, was assumed to be similar to the settling basin effluent at System 3, a beef feedlot similar in size, stocking density, and management. Constituent concentrations in the vegetative filter effluent of System 2 generally represent about a $70 \%$ reduction of the concentrations in the settling basin effluent.

Using the relationships between concentrations and distances developed for System 1 (Fig. 2 and 3) and the 61-m flow distance of System 2, the projected concentration reduction for constituents in the settling basin effluent after traversing System 2 would be about $65 \%$. This is close to the observed $70 \%$ reduction after $61 \mathrm{~m}$ of flow (Table 2). The comparison between the concentration reductions at System 1 and 2 indicates comparable and fairly consistent performance, although the flow distance of System 2 was considered inadequate to achieve an acceptable pollutant reduction.

The amount of nutrients removed by System 2 was not calculated, but most rainfall events of $<25 \mathrm{~mm}$ had no vegetative filter discharge. This indicated that retention of constituents as calculated on a weight basis would be greater than the $70 \%$ reduction on a concentration basis.

Average constituent concentrations in flow samples from System 3 are shown in Fig. 4 and 5. The concentration reductions at the System 3 sampling points are 


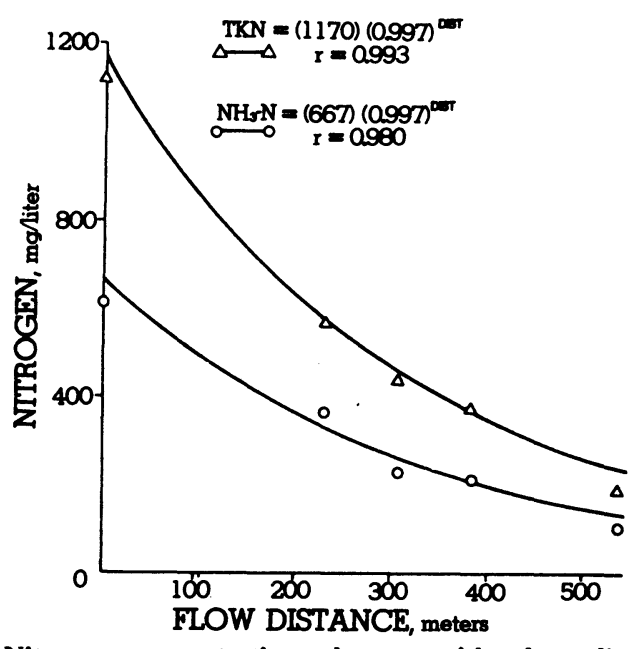

Fig. 4-Nitrogen concentration changes with channelized flow (System 3).

listed in Table 3. Comparing these reductions with those in System 1 and 2 (Tables 1 and 2) shows that a vegetative filter with channelized flow must be much longer than an overland flow system to achieve the same reduction. For example, overland flow systems have about a $70 \%$ concentration reduction after $90 \mathrm{~m}$ of flow, while channelized flow systems require about $427 \mathrm{~m}$ of flow distance to achieve a similar reduction.

Curvilinear regressions were used to develop relationships between constituent concentrations and flow length. The equations developed (Fig. 2, 3, 4, and 5) and $r$ values exceeding 0.95 . As with System 1, the data from System 3 also indicated that constituent concentrations approached background levels asymptotically.

Assuming that the filter discharge should meet current Illinois stream quality standards $\left(1.5 \mathrm{mg} \mathrm{liter}^{-1}\right.$ $\mathrm{NH}_{3}-\mathrm{N}$ and $1,000 \mathrm{mg} \mathrm{liter}^{-1}$ solids), the required filter length based on equations developed would be $154 \mathrm{~m}$ for System 1 and 2,030 m for System 3. Even though Systems 1 and 3 had nutrient retentions exceeding $90 \%$, in order to meet stream standards these filters should have had flow lengths 1.7 and 3.6 times longer, respectively. This procedure does not consider dilution potentials of receiving streams or additional runoff from surrounding areas.

During the 17-month study period (May 1976-October 1977) 10 storms resulted in discharges from System 3. Mass-balance studies were conducted for three rainfall events totaling $17.4 \mathrm{~cm}$. Using the average concentrations presented in Fig. 4 and 5 and the flow volumes measured for each storm, mass balances were calculated

Table 3-Reduction in constituent concentration in the basin effluent at various locations in the vegetative filter System 3.

\begin{tabular}{|c|c|c|c|c|}
\hline \multirow[b]{2}{*}{ Constituent } & \multicolumn{4}{|c|}{ Distance from basin discharge, $m$} \\
\hline & 229 & 305 & 381 & 533 \\
\hline & \multicolumn{4}{|c|}{ - concentration reduction, $\%$} \\
\hline $\begin{array}{l}\mathrm{NH}_{\mathbf{2}}-\mathrm{N} \\
\text { Total Kjeldahl-N } \\
\text { Total solids } \\
\text { COD } \\
\text { P }\end{array}$ & $\begin{array}{l}40.5 \\
49.6 \\
39.2 \\
49.2 \\
-\end{array}$ & $\begin{array}{l}62.9 \\
60.9 \\
59.0 \\
60.4 \\
16.0\end{array}$ & $\begin{array}{l}64.2 \\
66.3 \\
56.2 \\
67.4 \\
48.6\end{array}$ & $\begin{array}{l}83.4 \\
83.1 \\
79.7 \\
86.0 \\
-\end{array}$ \\
\hline
\end{tabular}

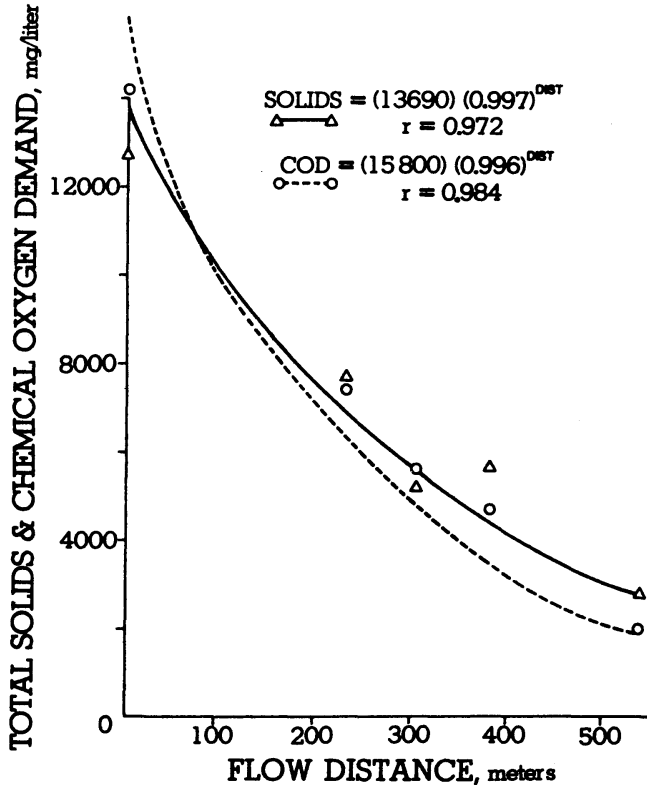

Fig. 5-COD and total solids concentration changes with channelized flow (System 3).

for four constituents (Table 4). About $30 \%$ of the constituents were removed in the first $229 \mathrm{~m}$ of flow, with the next $152 \mathrm{~m}$ removing an additional $50 \%$. The last $152 \mathrm{~m}$ of vegetative filter removed about $12 \%$ of the constituents. The resulting total constituent removal for System 3 was about $92 \%$ on a weight basis. For the three events, only $15.4 \mathrm{~kg}$ of ammonia- $\mathrm{N}$ was discharged from the filter. Assuming this measured quantity was representative of the other seven rainfall events (which were of about the same magnitude), the total ammonia-N discharged from System 3 would be 51.3 kg.

Low removal rates at the upper end of filter 3 reflected an inherent problem with a parabolic channel filter. Flow width in the waterway seldom exceeded 1.5 $\mathrm{m}$, primarily because of the controlled outflow from the settling basin. Grass in the waterway bottom was killed in a $0.3-$ to $0.9-\mathrm{m}$ width for about $9 \mathrm{~m}$. Vegetation was stunted for another $150 \mathrm{~m}$ beyond the killed area. Nutrients, solids, and water from most small runoff events were deposited or infiltrated in the waterway segment where vegetation was killed or stunted. Waterways with larger flow widths (such as flat-bottomed) apparently distributed basin effluent more evenly and might have alleviated the vegetation kill resulting from excessive nutrients and water in the narrow channel bottom.

The channelized filter, System 4, performed better than System 3. Average constituent concentration re-

Table 4-Constituent retention on a weight basis by vegetative filter System 3; average for three storms.

\begin{tabular}{lccc}
\hline & \multicolumn{3}{c}{ Distance from basin discharge, m } \\
\cline { 2 - 4 } Constituent & 229 & 381 & 533 \\
\hline & \multicolumn{3}{c}{ constituent retention, \% } \\
\cline { 2 - 4 } $\mathrm{NH}_{3}-\mathrm{N}$ & 24.3 & 80.0 & 92.3 \\
Total Kjeldahl-N & 35.8 & 81.2 & 92.2 \\
Total solids & 23.4 & 75.6 & 90.7 \\
COD & 34.0 & 81.8 & 93.5 \\
\hline
\end{tabular}




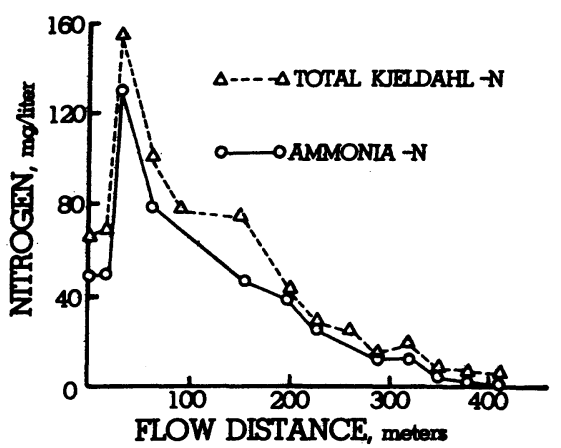

Fig. 6-Nitrogen concentration changes with channelized flow for an individual storm (System 4).

duction after $148 \mathrm{~m}$ of flow distance was about $86 \%$ (Table 5). Total solids were reduced $78.7 \%$ in the same distance. Higher pollutant removals than this are desirable and in this instance were achieved since the graded terrace discharged into an existing grass waterway. Figures 6 and 7 show constituent concentration along the filter of System 4 immediately after a 56-mm rainfall. Sampling immediately after rather than during the rainfall event probably resulted in the lower constituent concentration at the upper end of the terrace channel. The data for Systems 3 and 4 show that equivalent treatment requires longer flow lengths with channelized flow than with overland flow.

Results from monitoring soils, crops, and ground water in the filter areas studied are contained in a final project report (Vanderholm et al., 1979). The final report and an associated paper (Vanderholm and Dickey, 1978) also contain recommended design criteria and management practices.

\section{CONCLUSIONS}

Vegetative filters reduced nutrients, solids, and oxygen-demanding materials from feedlot runoff over $80 \%$ on a concentration basis and over $90 \%$ on a weight basis. Degree of pollutant removal was dependent upon type of flow (overland or channelized) and length of flow. Channelized flow systems were less effective than overland flow systems, and required much greater flow lengths for a similar degree of treatment. Constituent concentrations approached background levels asymptotically as flow length increased. Even though vegetative filters studied retained over $90 \%$ of the measured constituents, discharge concentrations did not meet stream quality standards. Using constituent concentration and flow-length relationships developed, the flow length required to meet standards would be two

Table 5-Constituent concentrations in System 4 settling basin and vegetative filter effluent after a flow distance of $148 \mathrm{~m}$.

\begin{tabular}{|c|c|c|c|}
\hline Constituent & $\begin{array}{c}\text { Settling basin } \\
\text { effluent }\end{array}$ & $\begin{array}{c}\text { Vegetative } \\
\text { filter effluent }\end{array}$ & $\begin{array}{c}\text { Constituent } \\
\text { reduction }\end{array}$ \\
\hline & ms & ter $\longrightarrow$ & $\%$ \\
\hline $\begin{array}{l}\mathrm{NH}_{3}-\mathrm{N} \\
\text { Total Kjeldahl-N } \\
\text { Total solids } \\
\text { COD }\end{array}$ & $\begin{array}{r}478 \\
1,081 \\
7,010 \\
11,063\end{array}$ & $\begin{array}{c}70.6 \\
120 \\
1,492 \\
871\end{array}$ & $\begin{array}{l}85.2 \\
88.9 \\
78.7 \\
92.1\end{array}$ \\
\hline
\end{tabular}

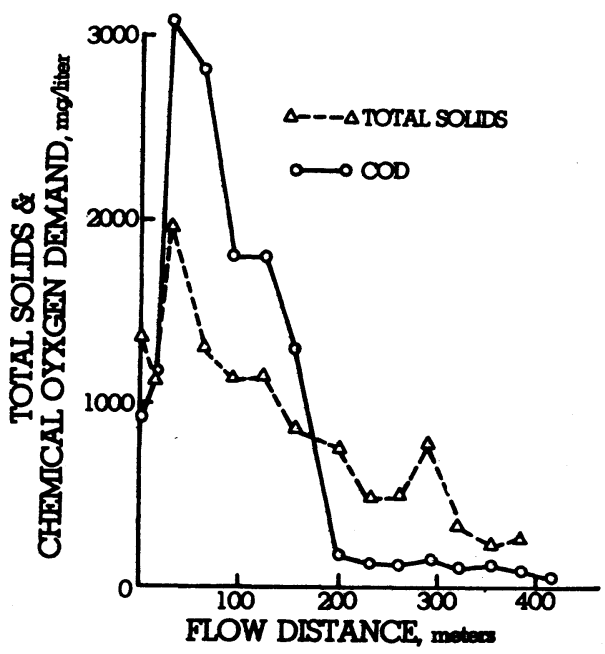

Fig. 7-COD and total solids concentration changes with channelized flow for an individual storm (System 4).

to four times longer than those evaluated. However, the relationships developed did not consider dilution potentials of receiving streams or additional runoff from surrounding areas.

Bacteria levels in feedlot runoff were not greatly reduced by vegetative filters. Fecal coliform levels of 1.05 $\times 10^{7} 100 \mathrm{ml}^{-1}$ in the filter discharge, and $5.75 \times 10^{5}$ $100 \mathrm{ml}^{-1}$ in the control-plot discharge receiving no feedlot runoff, were observed. Both of these values were high in relation to current stream standards, which range from $10^{2}$ to $10^{3} 100 \mathrm{ml}^{-1}$ depending upon location and stream use. Additional research is needed to accurately define bacterial quality for agricultural runoff and to aid in assessing the practicality of current stream standards.

To prevent damage to vegetation and reduced filter effectiveness, settling should be used to remove solids from feedlot runoff before application to filter areas.

Discharge from adequate size vegetation filters occurs only during large runoff events, which coincide with periods of high stream flows. The overall impact of multiple vegetative filter systems on receiving streams appeared to be negligible, but needs to be evaluated in more detail before these can be widely recommended and used. Vegetative filters can provide a satisfactory alternative to zero-discharge systems and result in reduced pollution problems associated with feedlot runoff.

\section{LITERATURE CITED}

1. American Public Health Association. 1975. Standard methods for the examination of water and wastewater. 14th ed. APHA, New York.

2. Bendixen, T. W., R. D. Hill, F. T. DuByne, and G. G. Robeck. 1969. Cannery waste treatment by spray irrigation-runoff. J. Water Pollut. Control Fed. 41:385-391.

3. Bremner, J. M., and D. R. Keeney. 1965. Steam distillation of Ammonium, nitrate, and nitrite. Anal. Chim. Acta 32:485-495.

4. Dickey, E. C., and D. H. Vanderholm. 1977. Feedlot runoff holding ponds - nutrient levels and related management aspects. J. Environ. Qual. 6:307-312.

5. Dornbush, J. N., J. R. Andersen, and L. L. Harms. 1974. Qualification of pollutants in agricultural runoff. U.S. Environmental 
Protection Agency. Rep. no. EPA-660/2-74-005. U.S. Government Printing Office, Washington, D.C.

6. Edwards, W. M., F. W. Chichester, and L. L. Harrold. 1971. Management of barnlot runoff to improve downstream water quality. p. 48-50. In Proc. Int. Symp. Livestock Wastes. 1922 Apr. 1971. Am. Soc. Agric. Eng., St. Joseph, Mich.

7. Kramer, J. A., D. E. Eisenhauer, R. I. Lipper, and H. L. Manges. 1974. A spray-runoff system with recirculation of treating beef cattle feedlot runoff. Am. Soc. Ag. Eng. Paper no. MC74-301. St. Joseph, Mich.

8. Mather, R. J. 1969. An evaluation of cannery waste disposal by overland flow spray irrigation. Publications in Climatology 22:2(1-73). C. W. Thornwaite Assoc., Centerton, N.J.

9. McCaskey, T. A., G. H. Rollins, and J. A. Little. 1971. Water quality of runoff from grassland applied with liquid, semiliquid and dry waste. p. 239-242. In Proc. Int. Symp. Livestock Waste. 19-22 Apr. 1971. Am. Soc. Agric. Eng., St. Joseph, Mich.

10. Sievers, D. M., G. B. Garner, and E. E. Picket. 1975. A lagoongrass terrace system to treat swine waste. p. 541-543. In Proc. 3rd Int. Symp. Livestock Wastes. Am. Soc. Agric. Eng., St. Joseph, Mich.

11. Sutton, A. L., D. D. Jones, and M. C. Brumm. 1976. A low cost settling basin and infiltration channel for controlling runoff from an open swine feedlot. Am. Soc. Agric. Eng. Paper no. 764516. St. Joseph, Mich.

12. Swanson, N. P., C. L. Linderman, and L. N. Mielke. 1975. Direct land disposal of feedlot runoff. p. 255-257. In Proc. 3rd Int. Symp. Livestock Wastes. Am. Soc. Agric. Eng., St. Joseph, Mich.

13. U.S. Environmental Protection Agency. 1974. Methods for chemical analysis of water and wastes. USEPA Rep. no. EPA625/6-74-00. U.S. Government Printing Office, Washington, D.C.

14. Vanderholm, D. H., and E. C. Dickey. 1978. Design of vegetative filters for feedlot runoff treatment in humid area. Am. Soc. Agric. Eng. Paper no. 78-2570. St. Joseph, Mich.

15. Vanderholm, D. H., E. C. Dickey, J. A. Jacobs, R. W. Elmore, and S. L. Spahr. 1979. Livestock feedlot runoff control by vegetative filters. U.S. Environmental Protection Agency Rep. no. EPA-600/2-79-143. U.S. Government Printing Office, Washington, D.C.

16. Willich, T. L., and J. O. Boda. 1976. Overland flow treatment of swine lagoon effluent. Am. Soc. Agric. Eng. Paper no. 764515. St. Joseph, Mich. 